\title{
50 Jahre Metallkunde-Kolloquium am Arlberg 50 $^{\text {th }}$ Anniversary of the Metallurgy Seminar in Arlberg
}

\section{Jahre Franz Jeglitsch 70 $^{\text {th }}$ birthday of Franz Jeglitsch}

I $\mathrm{m}$ April dieses Jahres fand das 50. MetallkundeKolloquium in der Region Arlberg (Tirol, Vorarlberg) mit einer großen Zahl von eingeladenen Vorträgen statt, welche in diesem Heft publiziert und zusätzlich Herrn o.Univ.-Professor Dr. Franz Jeglitsch zu seinem 70. Geburtstag gewidmet werden. Daher wird im Folgenden einerseits über die Historie des Metallkunde-Kolloquiums und andererseits zur Persönlichkeit Franz Jeglitsch berichtet.

Das Metallkunde-Kolloquium ist eine Einrichtung, die wie vieles andere - durch den unvergessenen Roland Mitsche ins Leben gerufen wurde. Roland Mitsche, geboren 1903, wurde 1940 zum Professor und Institutsvorstand des neu gegründeten Institutes für Metallkunde und Werkstoffprüfung an der Montanistischen Hochschule in Leoben berufen. Anfang Mai 1955 versammelte er eine Gruppe hochrangiger Vertreter aus Wissenschaft und Industrie (u.a. Professor Erich Schmid, einen der Väter der Plastizitätstheorie und späterer Präsident der Österreichischen Akademie der Wissenschaften) in St. Christoph am Arlberg zur „Sonnen-Hochgebirgs-Schi-Diskussionswoche“ über die ,Möglichkeiten und Grenzen der Anschaulichkeit in der Metallkunde" mit folgenden Themenschwerpunkten:

1. Quantentheorie, Wellenmechanik, Elektronentheorie der Metalle;

2. Gitterbau der Phasen in metallischen Systemen, Elektrische und Wärmeleitung;

3. Kristallbildung und -wachstum, ideale und reale Kristalle und Korngrenzen;

4. Umwandlungsvorgänge im festen Zustand mit und ohne Diffusion, Keimwirkungen, Spannungen;

5. Plastische Verformung, Verfestigung, Dämpfung, Bruchvorgänge.

Der Zweck dieser Veranstaltung war es, , . . . in einem nicht zu großen Kreise, völlig ungehemmt durch die bei sonstigen Fachveranstaltungen vorhandenen objektiven und subjektiven Hemmungen und Schwierigkeiten, in seelisch und geistig entspannter Atmosphäre ein echtes Gespräch über einige Themen zu führen, welche den Metallkundler ebenso bewegen wie den Physiker" (Zitat Mitsche). Die zweite Veranstaltung fand im April 1956 statt und zwar als einzige Ausnahme nicht am Arlberg, sondern in Hofgastein. Dieses Metallkunde- und Schikolloquium kehrte 1957 wieder nach St. Christoph zurück, wo die Veranstaltung bis 1978 jährlich wiederkehrend entweder im Hotel Arlberghöhe oder Hotel Hospiz stattfand. Von anfangs etwa 25 ,Auserwählten“ entwickelte sich die Teilnehmerzahl bis in die 70er Jahre etwa auf 70 Personen, wobei mittlerweile
$\mathrm{T}$ he $50^{\text {th }}$ Metallurgy Seminar was held in April this year in Arlberg (Tyrol, Vorarlberg). Numerous speakers were invited to give presentations, which are published in this issue and are dedicated to Professor Franz Jeglitsch on the occasion of his $70^{\text {th }}$ birthday. The following therefore gives an overview of the history of the Metallurgy Seminar as well as a portrait of Franz Jeglitsch.

The Metallurgy Seminar as an institution was brought into being, like so many other things, by the unforgotten Roland Mitsche. Born in 1903, Roland Mitsche became professor and director of the newly founded Institute of Metallurgy and Material Testing at Montan University in Leoben. At the beginning of May 1955 he gathered together a group of eminent representatives from science and industry (including Professor Erich Schmid, one of the fathers of plasticity theory and later president of the Austrian Academy of Sciences) in St. Christoph am Arlberg for a "sunmountain-ski-discussion week" focussing on "the possibilities and limitations of modelling in metallurgy". The following topics were emphasized:

1. Quantum theory, wave mechanics, electron theory of metals

2. Lattice structure of phases in metallic systems, electrical and thermal conductivity

3. Crystal formation and growth, ideal and real crystals and grain boundaries

4. Transformation processes in the solid state with and without diffusion, nucleation effects, stresses

5. Plastic deformation, work hardening, damping, fracture processes.

The aim of the event was "... to conduct a down-to-earth dialog in a small group on a few topics of passionate interest to both metallurgists and physicists, entirely unencumbered by the objective and subjective inhibitions and difficulties encountered at other seminars and in a psychologically and intellectually relaxed atmosphere" (Mitsche). The second event was held in April the following year in Hofgestein, marking the only time the seminar was not held in Arlberg. The metallurgy-and-ski seminar returned to St. Christoph in 1957, where it was held each year up to 1978 either at Hotel Arlberghöhe or at Hotel Hospiz. From the initial 25 "select invitees" the ranks of participants swelled to 70 in the 1970s, with up-and-coming scientists and younger industrial representatives participating in an active or passive role.

Following the death of Roland Mitsche in 1978 the $25^{\text {th }}$ Metallurgy Seminar, which was dedicated to the memory of Roland Mitsche, was held in St. Anton am Arlberg in 
auch Nachwuchswissenschafter und jüngere Industrievertreter aktiv und passiv mitwirkten.

Nach dem Tod von Roland Mitsche im Jahre 1978 wurde das 25. Metallkunde-Kolloquium ,In memoriam Roland Mitsche“ im April 1979 in St. Anton am Arlberg abgehalten, wobei die Vorträge in einem Doppelheft der RadexRundschau publiziert wurden. Zuvor erschienen bereits in den Jahren 1960, 1970, 1972 und 1977 derartige Sonderhefte. Von 1975 bis 1981 lag die verantwortliche Leitung bei Prof. Dr. Hellmut Fischmeister. Seit dem Frühjahr 1980 finden die Metallkunde-Kolloquien im Hotel Krone in Lech am Arlberg statt. Die organisatorische und wissenschaftliche Leitung wurde in den 80er Jahren von den Professoren Jeglitsch und Maurer wahrgenommen. Ab den 90er Jahren sind die Herren Professoren Jeglitsch und Kneissl hauptvertantwortlich für diese erfolgreiche Veranstaltung, die in den letzten 25 Jahren durchschnittlich etwa 80 Teilnehmer aus Österreich, Deutschland und der Schweiz und etwa 30 Vorträge aufwies.

Beim 50. Metallkunde-Kolloquium im April 2004 in Lech am Arlberg wurden neben den 14 in diesem Heft publizierten Einladungsvorträgen noch weitere 15 Kurzvorträge zu unterschiedlichen Themengebieten wie z. B. Mikrolegierte Stähle, Nickelbasis-Superlegierungen, Modellierung von Ausscheidungen, Magnesiumlegierungen, Beschichtungstechnik, Anwendung von FIB (Focused Ion Beam) in der Materialtechnik präsentiert.

Es steht zu hoffen und darf erwartet werden, dass dieses „Arlberg-Kolloquium“ auch in Zukunft Etablierte und Nachwuchs aus den Bereichen Wissenschaft, Forschung und Industrie in zwangloser Atmosphäre zusammenbringen wird, um auf hohem Niveau über Grundlagen, Einsatz und Entwicklungstendenzen von Werkstoffen zu informieren und zu diskutieren.

O. Univ.-Prof. Dr. mont. Dr. h. c. Franz Jeglitsch vollendet am 24. August 2004 sein 70. Lebensjahr. Im Editorial dieser Zeitschrift wurde er anlässlich seines 65. Geburtstages ausführlich gewürdigt (A. Kneissl, G. Petzow, Heft 8 (1999)), daher wird an dieser Stelle nur eine kürzere Laudatio präsentiert.

Franz Jeglitsch wurde 1934 in Klagenfurt, Kärnten, geboren und verbrachte den Großteil seiner Jugendzeit in Villach. Das Studium „Hüttenwesen“ an der damaligen Montanistischen Hochschule in Leoben schloss er 1958 mit Auszeichnung ab und begann seine berufliche und akademische Karriere am Institut für Metallkunde und Werkstoffprüfung. Nach der Promotion 1963 und der Habilitation 1968 wurde er 1973 zum Außerordentlichen Universitätsprofessor für ,Metallographie und metallkundliche Arbeitsverfahren“ ernannt. Von 1978 bis 1981 war er wissenschaftlich-technischer Geschäftsführer und Direktor des Österreichischen Forschungszentrums Seibersdorf, ehe er zunächst als Ordinarius für Technologie und Hüttenkunde der Nichteisenmetalle und ab 1982 als Ordinarius für Metallkunde und Werkstoffprüfung an die Montanuniversität zurückberufen wurde. In den Jahren 1987 bis 1991 war er ein überaus erfolgreicher Rektor der Montanuniversität, auf dessen unermüdlichen Einsatz die Schaffung mehrerer neuer Studienrichtungen und Institute zurückgeht. Von 1991 bis 2000 war er als Abgeordneter zum Steiermärkischen Landtag für die Bereiche Wissenschaft und Industrie sowie Kultur zuständig.
April 1979. The seminar papers were published in a double issue of the Radex Review. Similar special issues had also appeared in 1960, 1970, 1972 and 1977. From 1975 to 1981 Professor Hellmut Fischmeister was at the helm. Since the spring of 1980 the Metallurgy Seminars have been held at Hotel Krone in Lech am Arlberg. In the 1980s professors Jeglitsch and Maurer assumed organizational and scientific management of the event. Since the 1990s Professors Jeglitsch and Kneissl have been responsible for these successful conferences, which over the past 25 years have seen an average of 80 participants from Austria, Germany and Switzerland and at which some 30 presentations are given each year.

The $50^{\text {th }}$ Metallurgy Seminar was held in Lech am Arlberg in April 2004. Apart from the 14 papers published in this issue, a further 15 short presentations were given on a range of topics including microalloyed steels, nickel-based superalloys, modelling of precipitation processes, magnesium alloys, coating techniques and the use of focussed ion beams in materials science.

We have every hope that the Arlberg Seminar will continue to bring together established experts and rising stars from the science, research and industry communities in a relaxed atmosphere in which the participants can discuss and learn about the principles, applications and trends in materials science at the highest level.

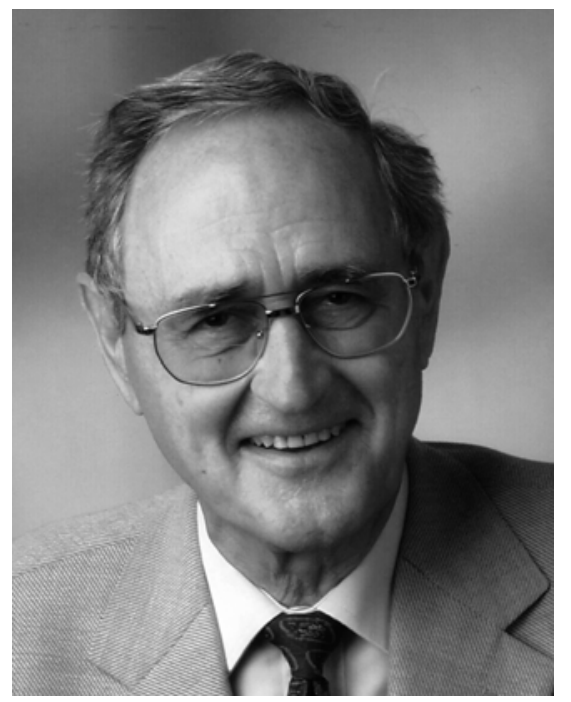

Professor Franz Jeglitsch will celebrate his $70^{\text {th }}$ birthday on 24 August 2004. Since Professor Jeglitsch was honoured at length in this column in 1999 on the occasion of his $65^{\text {th }}$ birthday (A. Kneissl, G. Petzow, Issue 8), a briefer eulogy is presented here.

Franz Jeglitsch was born in Klagenfurth, Austria in 1934 and spent most of his youth in Villach. He completed his studies in metallurgical engineering with distinction at the former Montan University in Leoben in 1958 and began his professional and academic career at the Institute of Metallurgy and Material Testing. After earning a PhD in 1963 and gaining university teaching qualifications in 1968, he was appointed supernumerary professor of metallography and metallurgical working processes. From 1978 to 1981 he served as scientific-technical manager and director of 
Neben seiner erfolgreichen Tätigkeit in akademischer Forschung (etwa 200 Publikationen) und Lehre (etwa 500 Studenten wurden unter seiner Ägide zu Diplomingenieuren für Werkstoffwissenschaft ausgebildet) war und ist Franz Jeglitsch in einer Vielzahl von universitären und außeruniversitären Gremien tätig, wobei nur eine kleine Auswahl vorgestellt wird: Mitglied der Schriftleitung und später Mitglied als wissenschaftlicher Beirat der Zeitschrift „Prakt. Metallographie“, Obmann des DGM-Metallographie-Ausschusses, Obmann des Metallographie-Ausschusses der Eisenhütte Österreich, Mitglied der Schriftleitung „Scanning“, Vorstandsmitglied der Forschungsgesellschaft Joanneum, Vorsitzender der Kommission für Wissenschaft und Forschung der Österreichischen Rektorenkonferenz, Mitglied des Direktoriums und des Senats der ChristianDoppler-Gesellschaft, 1997 bis 1998 Vorsitzender des Vorstandes der DGM, seit 2000 Vorsitzender des wissenschaftlichen Beirates des Kompetenzzentrums „Neue Materialien Nordbayern GmbH“, seit 2001 Vorsitzender des wissenschaftlichen Beirates von Joanneum Research.

Aus dem umfangreichen Bereich seiner Ehrungen seien ebenfalls nur die wichtigsten erwähnt: Sir Charles Hatchett Award des Institute of Materials (London), Henry Clifton Sorby Award der International Metallographic Society (IMS), ordentliches Mitglied der Österreichischen Akademie der Wissenschaften sowie der Academia Scientiarium et Artium Europaea, Ehrenmitglied der DGM, Ehrendoktorat der Yildiz Technischen Universität Istanbul, Roland Mitsche-Preis, Ehrenring der Stadt Leoben, Großes Goldenes Ehrenzeichen des Landes Steiermark, Großes Goldenes Ehrenzeichen der Republik Österreich.

Prof. Jeglitsch emeritierte zum 01. Oktober 2002 und ist nach wie vor innerhalb und außerhalb der Universität aktiv, wobei seine Meinung wohl gehört und hoch geschätzt wird. Seine starke familiäre Bindung und kulturellen und sportlichen Interessen ermöglichten ihm einen fließenden Übergang in die Emeritierung, wobei es weniger zu einer Verschiebung seiner Tätigkeiten als vielmehr der zeitlichen Gewichtung seiner Aktivitäten kommt.

Die Gasteditoren dieses Heftes wünschen zusammen mit den Autoren Herrn Prof. Jeglitsch und seiner lieben Gattin viele gute Jahre im Kreise der Familie, aber auch in Gesellschaft von Freunden und Kollegen, die gerne an seinem reichen Erfahrungsschatz und seiner Lebensweisheit teilnehmen wollen.

A. Kneissl, Ch. Mitterer, H. Clemens und G. Petzow, Leoben und Stuttgart the Austrian Research Centre in Selbarsdorf before returning to Montan University as professor of metallurgy and material testing. From 1987 to 1991 he was an extremely successful dean of Montan University. His tireless efforts saw the creation of several new fields of study and institutes. From 1991 to 2000 he became a member of parliament of the Styrian regional government responsible for science, industry and culture.

Apart from his successful career in academic research (around 200 publications) and teaching (some 500 students were trained as graduate engineers in material sciences under his aegis), Franz Jeglitsch was and is an active member on numerous university and nonuniversity committees, only a sample of which are mentioned here: member of the Editorial Board and later member of the Scientific Advisory Committee of the journal Praktische Metallographie (Practical Metallography); committee chair of the German Society of Metallurgy (DGM); chair of the Austrian Iron Foundry Metallography Committee; member of the editorial board of Scanning; committee member of the Joanneum Research Society; chair of the Science and Research Committee of the Austrian Dean Conference; member of the Board of Directors and Senate of the Christian Doppler Society; 1997 to 1993 chair of the DGM committee; since 2000 chair of the Scientific Committee of Neue Materialien Nordbayern GmbH; and since 2001 scientific committee chair of the Joanneum Research Society.

Likewise, only the most important of his many awards are mentioned here: Sir Charles Hatchett Award from the Institute of Materials (London), Henry Clifton Sorby Award from the international Metallographic Society (IMS), full member of the Austrian Academy of Sciences and the Academia Scientiarium et Artium Europaea, honorary member of the German Materials Society (DGM), honorary doctorate from Yildiz Technical University in Istanbul, Roland Mitsche Prize, Honorary Ring from the city of Leoben, the Great Golden Badge of Honor of Styria and the Great Golden Badge of Honor of the Republic of Austria.

Professor Jeglitsch became professor emeritus on 1 October 2002 and is still active within and outside the university, his opinions being well received and highly respected. His strong family ties and cultural and sporting interests have ensured a smooth transition to professor emeritus status.

The guest editors of this issue and the authors wish Professor Jeglitsch and his charming wife many happy years within his family environment but also in the company of friends and colleagues who wish to share his wisdom and wealth of experience.

A. Kneissl, Ch. Mitterer, H. Clemens and G. Petzow, Leoben and Stuttgart 